$6-2018$

\title{
Korean-English bilingual sibling interactions and socialization
}

Hyonsuk Cho

University of North Dakota, hyonsuk.cho@UND.edu

How does access to this work benefit you? Let us know!

Follow this and additional works at: https://commons.und.edu/tl-fac

Part of the Linguistics Commons

\section{Recommended Citation}

Hyonsuk Cho. "Korean-English bilingual sibling interactions and socialization" (2018). Teaching \& Learning Faculty Publications. 3.

https://commons.und.edu/tl-fac/3

This Article is brought to you for free and open access by the Department of Teaching and Learning at UND Scholarly Commons. It has been accepted for inclusion in Teaching \& Learning Faculty Publications by an authorized administrator of UND Scholarly Commons. For more information, please contact und.commons@library.und.edu. 


\title{
Korean-English bilingual sibling interactions and socialization
}

Hyonsuk Cho, University of North Dakota

\begin{abstract}
This paper examines how a pair of Korean-American siblings interact and socialize and how their interactions change over time as the younger sibling starts to go to an Englishspeaking preschool. A 7-year-old Korean-English bilingual girl and her 3-year-old sister were observed in their home over 23 visits within a year. Their discourse data, including $33 \mathrm{~h}$ of audio-recordings, were analyzed from the Language Socialization perspective. The older sibling's authority derived from the age-based Korean family hierarchy inevitably played a role in creating shared benefits in the bilingual sibling relationship. After the younger sibling began to speak English, there were noticeable changes in the power asymmetry and language parallelism - the younger sibling's repetition of older sibling's utterances. This study offers insight into the bidirectionality of sibling socialization processes of sibling interactions in relation to their bilingual and bicultural development.
\end{abstract}

Keywords: Siblings, Bilingual, Language socialization, Korean-American, Bidirectionality 


\section{Introduction}

The purpose of this paper is to examine Korean-English speaking siblings’ interactions in relation to their bilingual and bicultural development. When compared to language socialization research on adult-child or peer interactions, there is little research on bilingual siblings’ naturally-occurring interactions. Children's socialization has been frequently studied in the home context (Burdelski, 2010; Kang, 2013; Park, 2006; Watson-Gegeo \& Gegeo, 1986). When outof-the-home contexts were studied, peer interactions (Paugh, 2005; Song, 2009) or teacher-child interactions (He, 2011; Lo, 2009) were focused; sibling relationships have received relatively less attention especially those not initiated or mediated by their parents. Although peer and sibling relationships share similarities due to their similar developmental stages, sibling relationships possess some uniqueness. For example, at home, there is a "caregiving hierarchy." This is a social ranking based on the degree to which kinds of caregivers (e.g., a father vs. an older sibling) have more or less responsibility and authority as caregivers (Ochs, 1988). Children are at a lower caregiving hierarchy than their parents, but among siblings an older sibling has a higher status and authority. Such an ordering impacts their interactional dynamics and roles (Maynard, 2002). Furthermore, a particular culture or ideology of a family or of a community such as Korean’s age-based politeness can complicate sibling interactions. In Korean-American contexts, for example, parents teach hierarchical order in the family and polite behavior by prompting and modeling polite language and honorifics to their young children (Park, 2006). Korean children are explicitly taught appropriate terms for addressing a peer who is just one year older (Song, 2009).

Traditionally, Koreans’ belief systems and social structures are influenced by Confucian ideology. This ideology emphasizes hierarchical relationships between the parent and the child, 
between wife and husband, and between younger and older persons (Kim \& Wolpin, 2008). Furthermore, Korean parents in Korea would consider perfect Korean proficiency to be a natural and expected ability (Jeon, 2001) and adults at home and educators at school are conscious about teaching correct use of honorifics (Yoon, 2004). The traditional and conventional Korean discourses in South Korea, however, are often inconsistent with Korean-American metadiscourses as observed at the Korean language school (Lo, 2009), in the three-generation Korean-American home (Park, 2006), and in the Korean-American peer interactions (Song, 2009). This indicates that Korean traditional language and cultural ideologies do not fully capture Korean-American children’s interactions and development.

This paper aims to add to the existing research with Korean-American children by demonstrating how Korean-American siblings maintain and modify Korean traditional sibling hierarchical culture over time and how they develop their Korean and English languages and cultures and become competent bilingual and bicultural individuals. To that end, the paper is focused on young Korean-American siblings' interactions for a year. In the course of that year, the younger sibling began attending English-speaking preschool, and this impacted the siblings' interactions. This paper illustrates Korean-English speaking bilingual siblings' interactions in which their parents were not engaged. It shows how the siblings collaboratively develop their bilingual and bicultural competencies. The research questions are: (1) What are interactional patterns between Korean-American siblings at home? (2) How do their interactional patterns change over time as a younger sibling begins to speak English? To answer these questions, the researcher observed a 7-year-old Korean-English bilingual girl and her 3-year-old sister in their home. 


\section{Theoretical framework}

How novices are socialized through using language and how they use language to become a competent participant of a social group is the purview of language socialization (LS) (Ochs \& Schieffelin, 2012). For novices, language is viewed as a critical tool with which they can make meaning, to negotiate, and socialize in their culture. LS research examines not only linguistic development, but also the other forms of knowledge that are learned in and through language (Duff \& Talmy, 2011). Ochs (1986a) claimed that children and other novices in society acquire tacit knowledge of principles of social order and systems of beliefs through access to and participation in language-mediated interactions. Accordingly, LS focuses more on processes than outcomes, recording and explaining change in and the development of linguistic and cultural competence over time (Duff \& Talmy, 2011). That is, LS researchers strive to understand how socialization interactions affect the developmental trajectories of individuals, how they reflect larger systems and cultures, and how they are reproduced and transformed over time (Garrett, 2008).

LS holds that children, being creative and constructive in their socialization processes, have agency (Garrett \& Baquedano-López, 2002; Ochs \& Schieffelin, 2012). Agency in general is understood as children having the capacity to act, to react, to interact, and to influence their life. From the sociocultural perspective, agency is "the socioculturally mediated capacity to act" (Ahearn, 2001, p. 112) and is "constructed and renegotiated with those around the individual and with society at large” (Lantolf \& Pavelenko, 2001, p. 148). Agency develops in relation to social groups and through active collaboration with other actors (Deters, Gao, Miller, \& Vitanova, 2015). Such a perspective suggests that interaction has an indispensable relationship with agency (Deters et al., 2015; Said \& Zhu, 2017). Children learn social norms and rules not only through 
imitating adults and using available resources but also through creatively using cultural resources and contributing to the culture (Fogle \& King, 2013; Gaskins, Miller, \& Corsaro, 1992). Children have the autonomy and ability to make meaning and understand their environment. Thus, their socialization is promoted, not determined, by experts (Ochs \& Schieffelin, 2012). Accordingly, outcomes of a novice's language socialization are not necessarily the duplication of what the expert taught but can be hybrid practices—-the incomplete or partial appropriation, or rejection of target norms and practices (Duff, 2007; Paugh, 2005).

Taking the Neo-Vygotskian sociocultural perspective, LS researchers understand that culture is local, contextual, and flexible. Furthermore, LS acknowledges the role played by interlocutors (e.g., caregivers, teachers, peers) in helping novices learn the target norms and practices by means of scaffolding or guided participation (Duff, 2007). Although first language (L1) LS research has tended to focus on how novices are apprenticed to linguistic and cultural norms, second language socialization (SLS) research has tended to be more unpredictable, collaborative, co-constructed, and multi- /bidirectional (Bongartz \& Schneider, 2003; Duff \& Talmy, 2011; Fogle, 2012; Lo, 2009; Schecter \& Bayley, 2004; Talmy, 2008). Such mutual engagement and bidirectionality of language socialization between the expert and novice can lead to the learning opportunity and both benefit from it. While older children teach younger siblings, they can develop their own learning at the same time. Also, older children might act as a cognitive facilitator and younger siblings might act as a prompter and trigger (Gregory, 2001). Gregory (2001) argued that by highlighting the equality of roles between siblings, learning could go beyond definitions of scaffolding, such as unidirectional learning from a more experienced person to one less so and collaborative learning. 


\section{Literature review}

\subsection{Sibling influences and roles in language and behavior development}

Young children are more likely to imitate, ask more questions of, and request help from their older siblings than older peers; similarly, older siblings are more likely than older peers to spontaneously provide them more guidance (Azmitia \& Hesser, 1993). When first-born children start formal schooling, they bring the language and culture learned from the school into their home. Accordingly, younger siblings in bilingual homes have opportunities to learn the language and culture to be learned in school (Stevens \& Ishizawa, 2007; Yamamoto, 2001). Studies have shown that older siblings considerably impact their younger siblings' language production and use. In de la Piedra and Romo (2003), older siblings helped their 18-month old sister, L, participate in the collective literacy practices in their Spanish-English speaking home by adopting various pedagogical strategies (e.g., school games, notebooks, gestures, pretend play, etc.) and teaching English vocabulary. Older siblings were active agents, important mediators, collaborators, and mutual helpers in L's socialization process. According to Kibler, Palacios, and Simpson-Baird (2014), a strong predictor of a bilingual Latin@ child’s oral language production was the number of older siblings; having no impact were family income, maternal education, gender, and country of origin. Another important factor was whether older siblings were schoolaged or not. Bridges and Hoff (2014) found that the toddlers with older, school-aged siblings in English-Spanish bilingual homes used more English than Spanish and the toddlers had significantly higher English vocabulary scores than those without older siblings. This suggests that, in bilingual homes, older siblings are an important source of English language exposure for young children and that they have a significant influence on their younger siblings' English language development. 
Research on interactions between siblings have shown that older siblings often approved or sanctioned their younger siblings' language and behaviors and used terms that could make the hierarchical relationship evident. In teaching language and culture to their younger siblings, older siblings often utilize their authority and expertise (Kibler, Palacios, Simpson-Baird, Bergey, \& Yoder, 2016; Smith, 2014). In Nilep’s (2009) study, the older sibling Otoe displayed linguistic authority to her younger siblings. In this Japanese-American family, Otoe used codeswitching and disapproved of certain language and behavioral acts of her younger sister and brother. Otoe tried to teach her younger siblings what kinds of language use and behaviors were appropriate or inappropriate within the family. In a Chinese-English bilingual home, Chris keenly switched languages to maximize his power over his younger brother (Zhu, 2010). Chris would shift to Chinese from English and address himself as gege (older brother). Autonomously using his understanding of social value and power, Chris thus demonstrated his higher position in the family to convince his younger brother, who used only English, of his authority. Both older and younger brothers took up their agency and intentionally chose a language that could benefit their own argument.

In studying Mayan children’s talk in different households, Reynolds (2007) illustrated how siblings appropriated language structures and genres, including teasing, shaming, and insulting, in order to negotiate kin and peer alliances while also challenging hierarchies in intergenerational exchanges. When children acted out roles and characters that had more power than other interactants in pretend play or daily conversations, their language, voicing, and embodied practice became authoritative, imposing, and commanding. In their peer groups, children adopt adult roles and registers to exhibit their power (Goodwin, 1990; Kyratzis, 2004). When children play the role of mother in play, they use imperatives, indicating that children 
understand that the use of imperatives is a way to express dominance and power (Goodwin, 1990). In another study with Mayan siblings (de León, 2007), two male siblings—a 4- year-old and 2-year-old — were engaged in parallelism. According to Brown (1998), parallelism is the "repetition of all or a significant portion of the same proposition that was provided in the immediately prior turn” (p. 203). During a spontaneous play, the younger brother, Lol, repeated the basic greeting structure that the older brother, Jacinto, used (“are you there, X?”) and replaced X with a list of nouns (lizard, table, machete). The siblings’ verbal play represented how young siblings with agency appropriated and resisted the community's culture- the Mayan parallel structure in conversational interchanges.

As demonstrated in the previous studies, peer and sibling interactions differ from adultchild interactions. In children's interactions, the role of agency is clear in the processes of play, negotiation, and collaboration. Young children go beyond imitation by manipulating and transforming adults’ discourses and norms. Paugh (2005) stated that if only adult-child interactions had been observed, children's creative and innovative multilingual play would have been missed entirely. Furthermore, due to a family’s culture, sibling culture is more local than peer culture and young siblings’ interactional patterns vary depending on their family, language, and community cultures and resources. For a more nuanced understanding of peer culture and children's worlds in informal situations, more sibling research is needed. It would be beneficial to know how siblings from different age groups socialize, over time, with each other in diverse language and cultural contexts.

\section{Method}

\subsection{Focal siblings}


The older sibling, Meeso (all names are pseudonyms), and her three-year-old sister, Meejin, were both born and raised in the United States. Meeso's parents were born and grew up in South Korea. In their early 30s, they immigrated to the U.S. three years before Meeso was born. Meeso's father (heterosexual, cisgender) was studying religion and eventually took a job in the religious field in the U.S. Meeso's mother (heterosexual, cisgender) was a stay-at-home mother and volunteered in the Korean-American community. Her parents mainly spoke Korean to Meeso and Meejin. Meeso's mother did not enforce any strict rules relating to language use and learning (e.g., Korean-only policy at home) because she believed that her children would naturally develop both languages by attending the English-speaking school and using Korean at home, in the Korean church and the heritage language school. Meeso’s parents emphasized Korean traditional customs and values (e.g., politeness, greetings) as well as friendship between siblings. One of Meeso's mother's rules about the siblings getting along was the following: "If you fight over something, neither can have it.” Another rule was, "Listen to older people.” In Korean culture, age-based hierarchy has a significant impact on social interaction. Park (2006) stressed the importance of understanding the hierarchical system in the Korean culture for learning and using appropriate polite language.

They lived in a city in Western New York, where there was a high proportion of White and African American ethnic groups (89\%) and the percentage of languages other than English spoken at home was low (15\%; U.S. Census Bureau, 2010). The Korean population in this city was approximately $0.1 \%$ of the total population (U.S. Census Bureau, 2010). In this city, the proportion of people who spoke Asian and Pacific Islander Languages including Korean was steadily low (1286; 1.05\% in 2000, and 1629; 1.45\% during 2008-2012; U.S. Census Bureau, 2010). Closely following Meeso and Meejin for a year, the researcher clearly observed that the 
two had few chances to use Korean outside their home and the Korean-American community. They attended Korean-American church and went to Korean heritage language school on Sundays.

Meeso was in first grade at a public elementary school when the study began. Based on her academic reports and teacher interviews in first grade, Meeso’s academic performance was, in all areas, above average. It was evident that Meeso's oral and written language in English was stronger than in Korean considering the fluency, accuracy, and frequency. In both Englishspeaking (e.g., public school) and Korean-speaking (e.g., home) environments, Meeso mainly used English when interacting with the Korean-English bilingual researcher. Meejin stayed home with her mother until, midway through the study, she started attending a preschool. Meejin spoke Korean in general but as she started going to preschool her use of English increased.

The Korean-American church Meeso and Meejin regularly attended on Sundays offered a children’s hour-long sessions of a Christian worship service, Sunday school, and a Korean heritage language school for children. Aside from a boy who had recently come to the U.S., most children in the elementary group used English primarily. Four of them were first graders; the rest were third and sixth graders. Most children in Meejin’s preschool group were born in the U.S. and were emergent bilinguals, using more Korean than English. The Sunday school teacher for the elementary group, whose dominant language was English, was Korean-American. The English-fluent teacher for the preschool group was Korean and conducted class in Korean.

\subsection{Researcher role}

As a native speaker of Korean, the researcher could easily understand the language and behavior of relationship norms between siblings in the Korean-American family (e.g., 
Koreanspecific politeness). In many ways, however, the focal child's background was different from that of the researcher's. For example, Meeso was born and raised in the U.S. and from infancy was exposed to bilingual contexts. The researcher, who lived in Korea until her late 20s, has monolingual Korean-speaking parents. Meeso received her formal education in English. Through firsthand experience and parenting, Meeso's parents developed their own bilingualism. Such differences informed Meeso's interactions with her sister and offered the researcher a fresh perspective on Korean-American sibling interactions.

Although the researcher originally intended to be a quiet observer, Meeso and Meejin regularly invited her into their play. Collecting data as a participant observer is a common method in LS research (Garrett, 2008). The researcher became a full participant in the activities and created an environment wherein Meeso and Meejin felt comfortable. Meeso, Meejin, and the researcher played together or worked on some educational activities, such as literary activities and art projects. As a participant observer, the researcher could have impacted the siblings' interactions. The researcher was a facilitator, mediator, and questioner who asked the siblings to explain what was going on between the two at the moment. The researcher tried not to be like a teacher or controller who directed or regulated their interactions.

When the researcher visited Meeso's home, the interactions between mother and daughters were observed only for a little while and the father would leave for work, limiting the number of recordable occasions for natural interactions among the family. While the researcher interacted with Meeso and Meejin, their mother rarely interrupted the interaction, staying in another room or cooking in the kitchen. During an interview, Meeso's mother said that she and Meeso usually left each other alone. Meeso's mother neither helped Meeso with her homework as she did it herself nor asked about Meeso's school life in detail as Meeso enjoyed reading 
books, did her homework by herself, or played with Meejin after Meeso came back from school. Meeso's mother confirmed for the researcher that her usual interactional patterns with Meeso were similar to what the researcher saw.

\subsection{Data collection and data analysis}

Data, collected for a year, included digital audio or video recording files of observations, interviews, artifacts, and field notes mainly from their home and occasionally from the church. As the interaction between siblings was not frequent in the church, this paper mainly reports their interactions at home. The researcher visited their home 23 times (16 times in the spring and 7 times in the fall) as shown in Table 1. During the spring semester, the researcher observed the children at weekly intervals; less frequent in the fall, the researcher's visits their home amounted to once or twice a month, with observation lasting for one to two hours each time (total of $33 \mathrm{~h}$ ). During the observations, except for casual and spontaneous talk, Meeso read books in English and did art projects such as painting, craft, and drawing. Reading and art were two activities that Meeso enjoyed most at home and at school. Until Meejin started to go to English-speaking preschool, Meeso spoke Korean to Meejin. Meejin frequently interrupted Meeso when reading a book in English. After Meejin went to preschool, however, she began to speak and understand English at home and patiently looked at the books Meeso was reading, and responding to Meeso in English.

Considered for data analysis were the conversations that occurred when both Meeso and Meejin were present. Excluded from analysis were interactions between the researcher and Meeso without Meejin. An inductive process was used for data analysis (Corbin \& Strauss, 2008). In the first stage of analysis, video or audio recordings were watched or listened to and transcripts were read multiple times. A single interactive meaning unit was defined as a 
continuation of the same topic among the same participants in the same setting. The researcher began with open coding "to open up the data to all potentials and possibilities contained within them” (Corbin \& Strauss, 2008, p. 160). After all events were described by those lower-level concepts such as topic, language used, roles, way of speaking, and affect, the researcher looked for interactional patterns between the siblings and any changes over the course of time. Data were grouped using categories that emerged through this process. Recurring and representative interactional episodes exemplify the interactional patterns between the siblings and developmental changes observed during the study. Rather than generalize or simplify their sibling interactions, the goal of the analysis of interactional exchanges was to offer in-depth insights into these Korean-American siblings’ socialization processes. 
Table 1

Observation information.

\begin{tabular}{|c|c|c|c|c|}
\hline Visit & $\begin{array}{l}\text { Observation } \\
\text { date }\end{array}$ & Duration (h) & Major activities & Data types \\
\hline 1 & $12 / 09 / 2010$ & 1.5 & Reading books, doing an art project & AR, AF (Meeso's painting) \\
\hline 2 & $12 / 22 / 2010$ & 0.5 & Reading books & AR, Interview (Mom) \\
\hline 3 & $01 / 07 / 2011$ & 2 & Reading books, doing an art project & AR, AF (Meeso's playdough artwork) \\
\hline 4 & $01 / 21 / 2011$ & 1.5 & Reading books, craft & AR, AF (Meeso's origami artwork) \\
\hline 5 & $01 / 28 / 2011$ & 1 & $\begin{array}{l}\text { Reading books, playdate with Meeso's } \\
\text { friend (Korean-American) }\end{array}$ & AR \\
\hline 6 & $02 / 04 / 2011$ & 2 & $\begin{array}{l}\text { Reading e-books in Korean and in } \\
\text { English }\end{array}$ & $\begin{array}{l}\text { AR, Interview (Mom), Photos of Meeso talking, } \\
\text { reading on computer }\end{array}$ \\
\hline 7 & $02 / 11 / 2011$ & 1.5 & $\begin{array}{l}\text { Reading books, writing a valentine's } \\
\text { card to parents }\end{array}$ & AR, AF (Meeso's card) \\
\hline 8 & $02 / 18 / 2011$ & 1 & $\begin{array}{l}\text { Reading books, talking about family } \\
\text { and friends }\end{array}$ & AR \\
\hline 9 & $03 / 04 / 2011$ & 1.5 & Reading books, craft & AR, VR (0.5 h), AF (Meeso's artwork - mask) \\
\hline 10 & 03/18/2011 & 1 & Reading print and e-books, craft & AR, VR (0.5 h), AF (Meeso's artwork - Rapunzel) \\
\hline 11 & $04 / 01 / 2011$ & 1 & Reading books & AR, VR \\
\hline 12 & $04 / 15 / 2011$ & 1.5 & Reading books, painting & $\begin{array}{l}\text { AR, Photos of Meeso and Meejin reading and } \\
\text { doing an art project, AF (Meeso's and Meejin's } \\
\text { artwork) }\end{array}$ \\
\hline 13 & $04 / 22 / 2011$ & 1.5 & Reading books, painting & AR, Photos of Meeso and Meejin reading \\
\hline 14 & $04 / 29 / 2011$ & 1.5 & Reading books, craft & $\begin{array}{l}\text { AR, Photos of Meeso and Meejin reading and } \\
\text { doing art projects, Artifacts (Meeso's and } \\
\text { Meejin's artwork - necklaces, dinosaurs) }\end{array}$ \\
\hline 15 & $05 / 06 / 2011$ & 2 & Reading books, craft & $\begin{array}{l}\text { Interview (Mom), Photos of Meeso doing an art } \\
\text { project, Artifacts (Meeso's artwork - puzzle) }\end{array}$ \\
\hline 16 & $05 / 20 / 2011$ & 1.5 & Reading books, playing with playdough & AR, VR $(0.5 \mathrm{~h}), \mathrm{AF}$ (Meeso's playdough artwork) \\
\hline 17 & $09 / 03 / 2011$ & 1.5 & $\begin{array}{l}\text { [Meejin started to go to } \\
\text { English-speaking preschool] } \\
\text { Reading books, craft, painting }\end{array}$ & AR, VR (0.5 h), AF (Meeso's artwork) \\
\hline 18 & $09 / 23 / 2011$ & 1.5 & Reading books, craft, painting & AR, VR, AF (Meeso's artwork) \\
\hline 19 & $10 / 07 / 2011$ & 1.5 & Reading books, craft & AR, AF (Meeso's artwork - dog) \\
\hline 20 & $10 / 14 / 2011$ & 1 & Reading books, craft & AR, VR, AF (Meeso's artwork - necklace) \\
\hline 21 & $11 / 04 / 2011$ & 2 & Reading books, craft & AR, VR, AF (Meeso's artwork - craft) \\
\hline 22 & $11 / 18 / 2011$ & 1.5 & Reading books, playing cards & AR \\
\hline 23 & $12 / 09 / 2011$ & 1.5 & Painting and reading & AR, VR, AF (Meeso's painting), Interview (Mom) \\
\hline
\end{tabular}

Note. AR: audio-recording; VR: video-recording, AF: artifacts. 


\section{Findings}

\subsection{Interactional patterns between Korean-American siblings at home}

It was frequently observed that Meeso used her expertise in both English and Korean language and cultures and authority derived from the age-based family hierarchy. Meeso was aware of the power she had over Meejin and saw it to some extent as being absolute. When the researcher suggested that Meejin, when she turned 7, might be able to draw better than Meeso, Meeso reported, "I will still be older than her." The implication was that she would always be older and better than Meejin.

One of the frequent types of Meeso’s speech toward Meejin is known in Korean as honnayki — a way of talking to a younger person to scold and shame his or her inappropriate or impolite behavior (Lo \& Fung, 2012). Honnayki can be considered shaming in that it occurs when an adult wants to discipline a child and when an adult is frustrated by a child's inappropriate or incorrect behavior and use of language. The person who scolds has power and knowledge, usually a caregiver, an adult, or an older sibling (Lo \& Fung, 2012). In many cases, Meejin was constantly making noises or otherwise disturbing Meeso, while Meeso was reading by herself or talking with the researcher. In such cases, Meeso directed or restricted Meejin's behaviors ("hacima" ["Stop doing that"]). Meeso did not tend to explain to Meejin why she engaged in honnayki. She simply said, “Don’t do that” or "Stop it.” When Meejin would continually disturb her (e.g., putting her foot on the book Meeso was reading aloud or asking her to do something else), Meeso would curtly tell Meejin that she was reading a book or talking with the researcher. When her honnayki had no effect, Meeso told Meejin that she would tell their mother and that Meejin would receive honnayki from their mother, a threat that usually brought about the desired effect. Also, when Meejin spoke or behaved impolitely to her or the 
researcher, Meeso immediately corrected Meejin’s speech or behavior. One day, Meejin told the researcher that while she (Meejin) was pretty in her Cinderella costume the researcher would not be. Meeso scolded her: “That’s not nice!” Similarly, Meeso admonished Meejin to say “Thank you” at the Korean language school when a child let Meejin sit in her chair. Meejin, though, shook her head and refused.

Another common example of Meeso using her higher caregiving-hierarchy was when she used the family rules or parents' authority unfairly, as in Excerpt 1. What is interesting about Excerpt 1 is that Meeso constrained her younger sister's activity during a property dispute using their mother’s rule: “If you do not share, no one can have it.” Meeso acted unfairly when she took a drawing for Meejin’s coloring (Lines 1-5). Meeso tried to distract Meejin’s attention by giving her another drawing (Line 8), but when Meejin still disobeyed her, Meeso brought up the sharing rule. Meeso explained her mother's rule to the researcher in English, but to sound as though she had direct authority, Meeso did not quote her mother's rule to her sister in Korean. Quoting her mother could have undermined Meeso’s power. The way Meeso talked to her younger sister to discipline her was similar to that of her mother when disciplining either one of them. Another interesting point from Excerpt 1 is Meeso’s referring to herself “enni” [older sister] in Lines 8 and 10 instead of "me.” Her use of "enni” stressed her higher status and authority over Meejin.

\section{Excerpt 1: "Mom said. ..”}

(Before Meeso and Meejin began a coloring activity, Meejin picked a drawing of a mother from the coloring book. Korean is italicized and translation is in brackets.)

1 Meeso: (Grabbing a drawing of mother and putting it next to her) I'll do this later halkkeya. [will do] 2 Researcher: keken Meejin-i kkeya [That’s Meejin’s]. 
3 Meeso: ani [No]. I wanna do it because she doesn't know how to color 'mom'. She just scribbles.

4 Researcher: kwaynchana [That's fine for her to scribble].

5 Meeso: a sile. [Arr, I don't want to give it to her]

6 Researcher: Meejin-i ikehay, komtoliphu [Meejin, color this, Winnie-the-Pooh].

7 Meejin: (Whining, meaning she doesn't like to color a drawing of pooh)

8 Meeso: Meejin, ennika yeyppunke culkke kulem [Meejin, let your older sister (me) give you a pretty one then]. (Flipping the coloring book).

9 Meejin: Arr Arrr (Whining strongly, meaning she doesn't like other drawings than mother)

10 Meeso: (Saying to Meejin in Korean) ne enni mal an tulumyen ike mos hay [You can't do this, if you don't listen to your older sister (me)]. (Turning and talking to the researcher in English) Mom said if we fight over something we can’t play with it.

11 Meejin: Hmm (whining softly and briefly and stopped whining, indicating she still wants a drawing of mom but gives it up).

Furthermore, Meeso tried to take Meejin's possessions or told her to fetch something for her even when Meeso could do so herself (e.g., “thisyu kacye ollay, hyuci?” [Will you get me some tissue, toilet tissue?]). In Korean culture (e.g., Cang-Yu-Yu-Se-hierarchy exists between younger and older persons), children and younger people are expected to respect elun [an adult or someone who is older] — complying with the elder's directives, listening to his or her words, taking caring of him or her, and using honorific language. Meeso in these excerpts might be viewed as being greedy and selfish, but from the Korean cultural perspective she appropriated her authority within the acceptable range.

\subsection{Interactional change over time}

Different interactional patterns between Meeso and Meejin were observed as Meejin started to go to English-speaking preschool. Before Meejin spoke and understood English, Meeso provided language brokering help when Meejin tried to speak in English with the researcher. In Excerpt 2, Meejin asked whether the researcher had seen the movie The 
Incredibles (Line 1). When the researcher failed to grasp her meaning (Lines 2 and 4), Meeso clarified it and stated that Meejin’s English was “funny” (Line 5). Meejin did not comment on Meeso’s statement about Meejin’s English because she did not understand it.

Excerpt 2: "Do you know the Incredibles?”

1 Meejin: inkhlaylepul ala? Inkhlaylepul? [Do you know ‘incaruble’? 'incaruble’?]

2 Researcher: Uh? (Not understanding what Meejin said) kuke mweya? [What’s that?] 3 Meejin: inkhlaylepul ['incaruble']

4 Researcher: kuke mweya, Meesoya? [What's that, Meeso?]

5 Meeso: The Incredibles! Meejin’s English is funny hay. [is -be copula in Korean]. In Korean language culture, young people should not call older sister cyay [she/he or that person in Korean] (Excerpt 3, Line 2), or by name, but instead enni [older sister in Korean]. Address instruction implies sharing social rules as well as interpersonal relationships. Using address terms properly shows one’s understanding of sociocultural knowledge (Hanks, 1990). Meeso understood how to address a person higher in the family hierarchy using polite manners. When speaking to Meejin, Meeso’ mother referred to Meeso as enni (e.g., “enni hanthey mian hatago malhay” [Say sorry to your older sister]). Nevertheless, Meejin kept calling Meeso by name even after Meeso identified herself as enni to Meejin and asked Meejin to use enni, as shown below (Line 3).

Excerpt 3: "She did it.”

(Meejin was showing a painting of a dinosaur to the researcher.)

1 Researcher: nuka kulyesse? [Who drew this?]

2 Meejin: (Pointing at Meeso) cyayka haysse [She did it].

3 Meeso: cyayka malko enni [(You should call me) 'enni,' not 'she'].

Also, Meeso used enni to refer to herself to Meejin as shown in Excerpt 1 (Lines 8 and 10). When talking about something that belonged to her, Meeso said “enni kes [older sister's]" 
instead of "nay kes [mine]." This convention is similar to that used by teachers as the occupational title, senseyngnim [teacher] instead of na or ce [I, first person pronoun] (Byon, 2006).

However, using proper terms of address was important only when the children were speaking Korean. That is, as Meejin started to speak English in the middle of this year-long study, Meeso spoke English to Meejin. As Meejin’s English proficiency developed, the Korean address terms never came into play. Thus their conversation sounded like a conversation between English-speaking friends (Excerpt 4), with no indication of their social statuses within their family. Meejin referred Meeso “you” and Meeso referred to herself "I” instead of “enni” (Lines 1 and 2) When speaking in English, Korean speakers' places in the social hierarchy can go undetected as the tone of voice or the terms of address does not give any clue to the social relation.

Excerpt 4: "You're making rainbow"

(Meeso and Meejin are painting on a separate sheet of paper. Meejin was copying Meeso's painting - the sun and flowers over a green hill.)

1 Meejin: (Seeing Meeso drawing a curved line) You're making rainbow.

2 Meeso: I'm not making a rainbow.

In addition to Meejin’s Korean language development, Meeso influenced Meejin’s English language development by recasting her younger sister's English. Excerpt 4 is an example. When Meejin missed the article "a” in front of "rainbow" (Line 1), Meeso repeated Meejin's statement in its correct form (Line 2). While Meejin learned through her mistake with the help of her older sister, such an opportunity also helped Meeso develop awareness of grammatically (in)correct language structure. 
As Meejin began to speak English with Meeso, Meejin would imitate or use numerous utterances from Meeso which naturally led to more turns in English between the two siblings than before. Excerpt 5 was observed approximately three months after Meejin started going to preschool. While Meeso and Meejin were sharing a palette of paints, Meejin mixed up some paints, turning orange to brown. Meeso complained about the mix and called Meejin a baby (“she is a baby,” Line 3). Meejin defied her, saying, “I not a baby” (Line 4). Meejin used the sentence format Meeso used and replaced "she" with "I", but When Meeso said "yes you are" Meejin said "No" when she might have wanted to say "No I am not." The same pattern may be observed in Lines 9 and 10. Meejin repeated Meeso's sentence “I'm going to try red” but missed “am going to” but added “too.” In Line 13, Meejin repeated the researcher to imitate Meeso but missed “am (gonna).”

Excerpt 5: "I try red too"

(Meeso and Meejin were sitting on the table and painting on their own sketch pad. They shared a set of paints. Meejin mixed colors and made orange to brown paint.)

1 Meeso: Now I'm in trouble because what Mujin [Meejin] did. I wish Mujin [Meejin] is older.

2 Researcher: Meejin?

3 Meeso: I know I'm calling her Mujin because she is a baby.

4 Meejin: I not a baby.

5 Meeso: Yes you are.

6 Meejin: No.

7 Meeso: Then why are you like that (pointing at the mixed paint) and why did you mix up the paintings?

8 Meejin: Sorry.

9 Meeso: (Keeps painting) Now I'm going to try red.

10 Meejin: I try red too.

11 Researcher: Are you gonna write your name? 


\section{Meeso: Yeah!}

\section{Meejin: I gonna write my name.}

How Meejin reacted to Meeso’s evaluation of Meejin’s behavior (Lines 1-6) contrasted with Meejin’s reactions before Meejin went to preschool. Meeso often told the researcher that Meejin, because of her age, had yet become skillful at many things (e.g., Excerpt 1, Line 3 "She doesn’t know how to color mom”). Whenever Meeso made such evaluations in English, Meejin did not respond or react. In the beginning of the study, when Meeso said “Meejin doesn’t draw very well,” Meejin said nothing. When Meejin had a chance to draw a cat’s face during an origami craft project that they were doing together, Meeso snatched the origami paper, saying, “Meejin doesn’t know how to do eyes and stuff.” Again, Meejin said nothing. Interestingly, a slight change may be observed in Meeso’s attitude to Meejin. Meeso no long declared what Meejin “could not do” or “did not know.” As in Excerpt 5, although Meeso would point out how Meejin made trouble, Meeso did not stop her from participating in play or reading or art activities but let her continue doing them in her own fashion. Such forbearance could indicate that Meeso was aware that Meejin could understand what Meeso said in English and Meejin did not bother her as significantly as before.

\section{Discussion}

\subsection{Collaboration and mutual benefits}

Language socialization (LS) occurs when more than two individuals interact and collaborate with each other. Bidirectionality in LS denotes collaboration. As the data of the current study has illustrated, however, collaboration does not necessarily mean equality between the participants. One participant can have more power and authority at one moment but the other participant can play the same role at another moment. In other words, they can be "unequal 
collaborators" or “orchestrators of events” (Maynard, 2002, p. 978). During the collaborative process, Meeso took on a teacher's role in many instances during her interactions with Meejin. Meeso's role as a teacher was largely oriented from her age and experience as similarly observed in other cultural contexts (Kibler et al., 2016; Nilep, 2009; Smith, 2014). The age-based Korean family hierarchy gave Meeso a unique position of authority over Meejin. Their mother often told Meejin to "listen to your older sister [Meeso]" when their mother could not be nearby or could not take part in their play. Meeso's mother often told Meeso to listen to older people including the researcher, teachers, and parents ("sensayng-nim malssum caltule" [Listen to the teacher well]). Moreover, Meeso's knowledge of Korean and English languages and culture allowed her to teach Meejin linguistic and sociocultural knowledge spontaneously. Using her authority and knowledge, Meeso used directives in Korean when using and showing Meejin her authority and hierarchy in the family. Meeso sometimes did not attribute the rule regarding play to her mother, speaking as though the rule was Meeso’s. Such a choice represents her agency and her appropriation of the rule she learned from her mother (de León, 2007; Duff, 2007; Ochs \& Schieffelin, 2012). Meeso might have invoked the rule to ensure peaceful and fair play but she may also have done so simply because she wanted to. Yet, when Meeso pointed out Meejin's disruptive or rude behaviors using a shaming and discipline practice—-known in Korean as honnayki-Meeso wanted Meejin to learn "how to be part of the community, rather than set [her] apart” (Schieffelin, 1986, p. 179). The manner of the older sibling's teaching can be distinguishable from that of another culture-oriented bilingual family in the U.S. Still it might be common across cultures for older siblings to teach younger siblings rules, knowledge, and skills that are necessary and appropriate in their family. 
It should be noted that Meeso's teaching was not unidirectional and their socialization was mutually beneficial to both. First, Meejin occasionally initiated and triggered the teaching by refusing to follow Meeso's directives (e.g., asking for Meeso's confirmation on whether to avoid taking food that Meejin was allergic to, stating a grammatically incorrect sentence, saying English words incomprehensibly, and interrupting Meeso). During the collaborative interactions, Meeso made Meejin aware of the following things: (1) behaviors and languages that can be applied to both Korean- and English-speaking contexts—socially inappropriate behaviors such as making disturbing noise or interrupting others and socially inappropriate language such as statements that could embarrass the listener are not desirable, (2) language that is applicable only in a Korean-speaking context: culturally appropriate language (e.g., use of appropriate address terms such as enni) and rules that are agreed upon in their family such as the sharing rule and respectingadults rule should be used, and (3) language that is applied to the English-speaking context including grammatically correct English and comprehensible pronunciation of English words. Such linguistic, cultural, and behavioral knowledge is important for Meejin to grow as a bilingual and bicultural child, as she was an emergent bilingual beginning to develop speaking abilities in both English and Korean.

Second, Meeso benefited from teaching Meejin. Meeso practiced her knowledge of Korean and English languages and cultures by socializing Meejin. Meeso’s knowledge could become stronger as she expressed and represented it in real life. "Older children learn," according to Gregory (2001), "through practicing consciously what they know and through translating official meanings into personal sense and vice versa for the younger child” (p. 318). Meeso increased her understanding of challenges that second language learners may encounter 
by language brokering for her sister and by correcting her sister's English. Furthermore, Meeso could maintain and develop her Korean language and cultural background by teaching Meejin.

\subsection{Development and change During the observation}

Meejin started to learn English and Meeso and Meejin increasingly used English rather than Korean. Meejin repeated what Meeso just said. Meejin used the same sentence structure but replaced a word (“you” to "I”) or added a word (“too”) even though Meejin missed some grammatical words such as a be-copula "am" or an article "a." Scholars studying discourse have identified such repetition strategies as "parallelism"-repetition of a large portion of the same proposition that was provided in the immediately prior turn (Brown, 1998) or "format tying"—an argumentative move that tie to prior ones by reusing materials in the earlier talk (Corsaro \& Maynard, 1996; Goodwin, 1990). Mayan speakers managed repetition to convey agreement, collaboration, and confrontation, and Mayan children utilized this feature of conversational interchanges in their play (de León, 2007). Samoan children repeated their caregivers’ affectloaded speech to convey feelings (Ochs, 1986b). It is clear that repetition is pervasive in children's conversations, but what is interesting in the interactions between Meeso and Meejin is that Meejin's repetition was ungrammatical, which reflected her developmental status in English language acquisition. To Meejin, repetition was her communication strategy and her communicative resource, rather than solely an “imitation” (Howard, 2009; Keenan, 1977). Repetition in children's language play helps them “develop and display metalinguistic awareness, more particularly, awareness of the repeating patterns that constitute various genres and types of talk (Moore, 2012, p. 216). Children learning a second language use repetition to gain access to and participate in play (Cekaite \& Aronsson, 2006; Pallotti, 2002). In this regard, emerging bilingual children's repetition represents their own agency in learning language and 
joining their peers' and siblings' worlds. Meejin's repetition of Meeso' utterances and the parallelism indicate that Meejin was relying on Meeso in her English language development.

Another change in their linguistic and social interactions after Meejin started to speak English was a change in the power asymmetry between the two. When they spoke English, the asymmetrical power balance created by the Korean language system and agebased family hierarchy was not easily detectable. In Korean culture, kinship terms are clear indicators of hierarchy. When Meeso stressed her enni status, she had an advantage over Meejin during a property dispute. If English is used between Korean speakers, the inherent hierarchy of their relationship can go undetected. In Song (2009), children used Anglicized Korean names to avoid using kinship terms such as enni [sister] or hyeng [brother] to their peers who were just one year older because when English is used for conversation, the Korean kinship terms are unnecessary. On one hand, the use of English created a new environment for them that was different from Korean-speaking situations. On the other hand, a decrease in the input sources for Meejin's heritage language development could affect the child's heritage language maintenance.

\section{Conclusion}

This paper has focused on Korean-American siblings’ bilingual and bicultural socialization process at home. As a case study with a pair of Korean-English bilingual siblings, the findings of this study cannot be generalized to bilingual siblings whose first and second languages are different, whose home environment is different (e.g., the number of siblings, degree or quality of parental engagement, ages of and age gaps between siblings), and whose community context is different (e.g., more opportunities to use Korean in LA). Also, unlike the older siblings in previous studies who pretended to teach and invited their younger siblings to read books (Gregory, 2001; Kibler et al., 2014), Meeso preferred not to read books to/for Meejin 
or explain how to do something to her. This could have been due to a number of reasonsMeejin’s English level, Meeso’s preference to use English, Meejin’s lack of interests in book reading, or the four-year age gap separating them. That indicates that, depending on an individual's preference or characteristics, siblings may engage in different dynamics of socialization. Future studies that address these various contexts and situations will enhance the understanding of sibling socialization.

This study offers insight into the bidirectionality of sibling socialization processes that Korean-American siblings can engage in while in their homes. Piagetian and Vygotskian perspectives generally agree that an asymmetry of knowledge but not authority leads to ideal learning (Tudge \& Rogoff, 1989). The current study, however, suggests that authority stemming from a caregivinghierarchy and a family's cultural background inevitably plays a role in KoreanEnglish bilingual siblings. The culture-oriented hierarchy still results in collaboration and shared benefits in the bilingual sibling relationship. Bilingual siblings can consciously and unconsciously engage in the exercise of power, but at the same time they cooperate and help one another as mutual apprentices to be socialized into local culture and social norms (de la Piedra \& Romo, 2003; Pontecorvo, Fasulo, \& Sterponi, 2001). Furthermore, this study reported the sibling discourses that changed over time as the younger sibling started speaking English. As children grow older, their knowledge and experience might affect social dynamics between them. More LS research is needed that illustrates how sibling interactions affect the developmental trajectories of children in different contexts over time and how the sibling socialization reflects larger systems and cultures.

\section{Note}

Korean is transcribed according to the Yale Romanization system and written in italics. 


\section{Acknowledgements}

I am grateful to anonymous reviewers and the editors for their insightful, critical, and supportive comments and suggestions. 


\section{References}

Ahearn, L. M. (2001). Language and agency. Annual Review of Anthropology, 31, 109-137.

Azmitia, M., \& Hesser, J. (1993). Why siblings are important agents of cognitive development: A comparison of siblings and peers. Child Development, 64(2), 430-444.

Bongartz, C., \& Schneider, M. L. (2003). Linguistic development in social contexts: A study of two brothers learning German. The Modern Language Journal, 87, 13-37.

Bridges, K., \& Hoff, E. (2014). Older sibling influences on the language environment and language development of toddlers in bilingual homes. Applied Psycholinguist, 35(2), 225-241.

Brown, P. (1998). Conversational structure and language acquisition: The role of repetition in Tzeltal. Journal of Linguistic Anthropology, 8, 197-221.

Burdelski, M. (2010). Socializing politeness routines: Action, other-orientation, and embodiment in a Japanese preschool. Journal of Pragmatics, 42(6), 1606-1621.

Byon, A. S. (2006). Language socialization in Korean-as-a-foreign-language classrooms. Bilingual Research Journal, 30, 265-291.

Cekaite, A., \& Aronsson, K. (2006). Language play, a collaborative resource in children's L2 learning. Applied Linguistics, 26, 169-191.

Corbin, J., \& Strauss, A. (2008). Basics of qualitative research: Techniques to developing grounded theory (3rd ed.). Los Angeles, CA: Sage.

Corsaro, W. A., \& Maynard, D. W. (1996). Format tying in discussion and argumentation among Italian and American children. In D. L. Slobin, J. Gerhardt, A. Kyratzis, \& J. Guo (Eds.), Social interaction, social context, and language (pp. 157-174). Mahwah, NJ: Lawrence Erlbaum Associates.

de la Piedra, M., \& Romo, H. (2003). Collaborative literacy in a Mexican immigrant household: The role of sibling mediators in the socialization of pre-school learners. In R. Bayley, \& S. R. Schecter (Eds.), Language socialization in bilingual and multilingual societies (pp. 44-61). Clevedon, UK: Multilingual Matters. 
de León, L. (2007). Parallelism, metalinguistic play, and the interactive emergence of Zinacantec Mayan siblings' culture. Research on Language and Social Interaction, 40, 405-436.

Deters, P., Gao, X., Miller, E. R., \& Vitanova, G. (Eds.). (2015). Theorizing and analyzing agency in second language learning: Interdisciplinary approaches. Buffalo, NY: Multilingual Matters.

Duff, P. (2007). Second language socialization as sociocultural theory: Insights and issues. Language Teaching, 40, 309-319.

Duff, P., \& Talmy, S. (2011). Language socialization approaches to second language acquisition: Social, cultural, and linguistic development in additional languages. In D. Atkinson (Ed.), Alternative approaches to SLA (pp. 95-116). London: Routledge.

Fogle, L. W. (2012). Second language socialization and learner agency: Adoptive family talk. Bristol, UK: Multilingual Matters.

Fogle, L. W., \& King, K. A. (2013). Child agency and language policy in transnational families. Issues in Applied Linguistics, 19, 1-25.

Garrett, P. (2008). Researching language socialization. In K. A. King, \& N. H. Hornberger (Eds.), Encyclopedia of language and education, Vol. 10: Research methods in language and education (2nd ed., pp. 189-201). Boston, MA: Springer.

Garrett, P., \& Baquedano-López, P. (2002). Language socialization: Reproduction and continuity, transformation and change. Annual Review of Anthropology, 31, 339-361.

Gaskins, S., Miller, P. J., \& Corsaro, W. A. (1992). Theoretical and methodological perspectives in the interpretive study of children. In W. A. Corsaro, \& P. J. Miller (Eds.), Interpretive approaches to children's socialization, New directions for child development (Vol. 58) (pp. 5-23).

Goodwin, M. H. (1990). He-said-she-said: Talk as social organization among black children. Bloomington, IN: Indiana University Press. 
Gregory, E. (2001). Sisters and brothers as language and literacy teachers: Synergy between siblings playing and working together. Journal of Early Childhood Literacy, 1(3), 301322.

Hanks, W. F. (1990). Referential practice: Language and lived space among the Maya. Chicago: The University of Chicago Press.

He, A. W. (2011). Language socialization. In J. Simpson (Ed.), Routledge handbook of applied linguistics (pp. 287-302). New York: Routledge.

Howard, K. (2009). Breaking in and spinning out: Repetition and decalibration in Thai children's play genre. Language in Society, 38, 339-363.

Jeon, M. (2001). Avoiding FOBs: An account of a journey. Working Papers in Educational Linguistics, 17(1-2), 83-106.

Kang, H.-S. (2013). Korean-immigrant parents' support of their American-born children's development and maintenance of the home language. Early Childhood Education Journal, 41, 431-438.

Keenan, E. O. (1977). Making it last: Repetition in children’s discourse. In S. Ervin-Tripp, \& C. Mitchell-Kernan (Eds.), Child discourse (pp. 125-138). New York: Academic Press.

Kibler, A. K., Palacios, N., \& Simpson-Baird, A. (2014). The influence of older siblings on language use among second-generation Latino preschoolers. TESOL Quarterly, 48(1), 164-175.

Kibler, A. K., Palacios, N., Simpson-Baird, A., Bergey, R., \& Yoder, M. (2016). Bilingual Latin@ children’s exposure to language and literacy practices through older siblings in immigrant families. Linguistics and Education, 35, 63-77.

Kim, E., \& Wolpin, S. (2008). The Korean American family: Adolescents versus parents acculturation to American culture. Journal of Cultural Diversity, 15(3), 108-116.

Kyratzis, A. (2004). Talk and interacting among children and the co-construction of peer groups and peer culture. Annual Review of Anthropology, 33, 625-649. 
Lantolf, J. P., \& Pavelenko, A. (2001). (S)econd (L)anguage (A)ctivity: Understanding learners as people. In M. Breen (Ed.), Learner contributions to language learning: New directions in research (pp. 141-158). London: Pearson.

Lo, A. (2009). Lessons about respect and affect in a Korean heritage language school. Linguistics and Education, 20, 217-234.

Lo, A., \& Fung, H. (2012). Language socialization and shaming. In A. Duranti, E. Ochs, \& B. B. Schieffelin (Eds.), The handbook of language socialization. United Kingdom: Blackwell Publishing Ltd.

Maynard, A. E. (2002). Cultural teaching: The development of teaching skills in Maya sibling interactions. Child Development, 73(3), 969-982.

Moore, L. (2012). Language socialization and repetition. In A. Duranti, E. Ochs, \& B. B. Schieffelin (Eds.), The handbook of language socialization (pp. 210-226). United Kingdom: Blackwell Publishing Ltd.

Nilep, C. (2009). Sibling interaction and symbolic capital: Toward a theory of political microeconomy. Journal of Pragmatics, 41, 1683-1692.

Ochs, E. (1986a). Introduction. In B. B. Schieffelin, \& E. Ochs (Eds.), Language socialization across cultures (pp. 1-13). New York: Cambridge University Press.

Ochs, E. (1986b). From feelings to grammar: A Samoan case study. In B. B. Schieffelin, \& E. Ochs (Eds.), Language socialization across cultures (pp. 251-272). New York: Cambridge University Press.

Ochs, E. (1988). Cultural and language development: Language socialization and language acquisition in a Samoan village. Cambridge: Cambridge University Press.

Ochs, E., \& Schieffelin, B. B. (2012). The theory of language socialization. In A. Duranti, E. Ochs, \& B. B. Schieffelin (Eds.), The handbook of language socialization (pp. 1-21). United Kingdom: Blackwell Publishing Ltd. 
Pallotti, G. (2002). Borrowing words: Appropriations in child second-language discourse. In J. Leather, \& J. van Dam (Eds.), The ecology of language acquisition (pp. 183-203). Amsterdam, The Netherlands: Kluwer Academic Publishers.

Park, E. (2006). Grandparents, grandchildren, and heritage language use in Korean. In K. KondoBrown (Ed.), Heritage language development: Focus on East Asian immigrants (pp. 5786). Amsterdam, The Netherlands: John Benjamins.

Paugh, A. L. (2005). Multilingual play: Children’s code-switching, role play, and agency in Dominica, West Indies. Language in Society, 34(1), 63-86.

Pontecorvo, C., Fasulo, A., \& Sterponi, L. (2001). Mutual apprentices: The making of parenthood and childhood in family dinner conversations. Human Development, 44, 340361.

Reynolds, J. F. (2007). "Buenos Días ((Military Salute))”: The natural history of a coined insult. Research on Language and Social Interaction, 40, 437-465.

Said, F., \& Zhu, H. (2017). “No, no Maama! Say ‘Shaatir ya Ouledee Shaatir’” Children’s agency in language use and socialization. International Journal of Bilingualism, 1-17. http://dx.doi.org/10.1177/1367006916684919

Schecter, S. R., \& Bayley, R. (2004). Language socialization in theory and practice. International Journal of Qualitative Studies in Education, 17, 605-625.

Schieffelin, B. B. (1986). Teasing and shaming in Kaluli children's interactions. In B. B. Schieffelin, \& E. E. Ochs (Eds.), Language socialization across cultures (pp. 165-181). Cambridge: Cambridge University Press.

Smith, B. (2014). Metacultural positioning in language socialization: Inhabiting authority in informal teaching among Peruvian Aymara siblings. Linguistics and Education, 25, 108118.

Song, J. (2009). Bilingual creativity and self-negotiation: Korean American children’s language socialization into Korean address terms. In A. Reyes, \& A. Lo (Eds.), Beyond yellow English: Toward a linguistic anthropology of Asian Pacific America (pp. 213-232). New York: Oxford University Press. 
Stevens, G., \& Ishizawa, H. (2007). Variation among siblings in the use of a non-English language. Journal of Family Issues, 28, 1008-1025.

Talmy, S. (2008). The cultural productions of ESL student at Tradewinds High: Contingency, multidirectionality, and identity in L2 socialization. Applied Linguistics, 29, 619-644.

Tudge, J. R., \& Rogoff, B. (1989). Peer influences on cognitive development: Piagetian and Vygotskian perspectives. In M. H. Bornstein, \& J. S. Brunner (Eds.), Interaction in human development (pp. 17-40). Hillsdale, NJ: Erlbaum.

U.S. Census Bureau. (2010). State and county QuickFacts.. Retrieved from http://quickfacts.census.gov/qfd/states/36/3611000.html

Watson-Gegeo, K. A., \& Gegeo, D. W. (1986). Calling-out and repeating routines in Kwara'ae children's language socialization. In B. B. Schieffelin, \& E. E. Ochs (Eds.), Language socialization across cultures (pp. 17-50). Cambridge: Cambridge University Press.

Yamamoto, M. (2001). Language use in interlingual families: A Japanese-English sociolinguistic study. Clevedon, UK: Multilingual Matters.

Yoon, K.-J. (2004). Not just words: Korean social models and the use of honorifics. Intercultural Pragmatics, 1-2, 189-210.

Zhu, H. (2010). Language socialization and interculturality: Address terms in intergenerational talk in Chinese diasporic families. Language and Intercultural Communication, 10, 189205. 